\title{
Action of booster immunization with E2 CSFV on immune response elicited by marker DNA-vaccine against CSF
}

\author{
Ia. O. Pokholenko, T. P. Gulko, O. G. Deryabina' ${ }^{1}$, . A. Kordium \\ Institute of Molecular Biology and Genetics, NAS of Ukraine \\ 150, Akademika Zabolotnoho Str., Kyiv, Ukraine, 03680 \\ ${ }^{1}$ Institute of Veterinary Medicine, NAAS of Ukraine \\ 30, Donetska Str., Kyiv, Ukraine, 03151 \\ yasnenka@gmail.com
}

\begin{abstract}
Aim. The aim was to study the influence of booster immunization with recombinant fragment of E2 CSFV on humoral immune response, elicited by candidate marker DNA-vaccine against CSF. Methods. The fragment of E2 CSFV gene has been detected by PCR, and the expres- sion of encoded protein - by immunohistochemical analysis. The anti-E2 antibodies in blood serum after immunization have been detected by ELISA. Results. It has been shown that candidate marker DNA-vaccine transfected myocytes of murine biceps in situ. The data of immuno-histochemical analysis revealed the expression of fragment of glycoprotein E2 CSFV from the plasmid introduced. The booster immunization with recombinant E2 led to the significant increase of the titer of antibodies specific to the antigen studied. Conclusions. The data obtained show that boosting with recombinant E2 enhances humoral immune response elicited by the candidate marker DNA-vaccine against CSF.
\end{abstract}

Keywords: marker DNA-vaccine, booster immunization, humoral immune response, classical swine fever virus.

Introduction. Classical swine fever (CSF) is a dangerous highly contagious disease. It is included into the list $\mathrm{A}$ of the Office International des Epizooties (OIE). Periodic outbreaks of this disease, observed everywhere except for USA, Canada, Australia, New Zealand, Iceland, Ireland, Norway and Sweden, are of considerable damage to animal husbandry. The causative agent of this disease is a member of Flaviviridae family - the virus of classical swine fever (CSFV). The attenuated vaccines against CSF, present in the market, do not provide for serological discrimination between post-infectious and vaccine-induced immunity. This aspect is especially significant in detecting chronically infected

(C) Institute of Molecular Biology and Genetics, NAS of Ukraine, 2012 animals which do not develop any clinical signs of the disease for a long time, and thus, may be a source of spreading virulent CSFV in the livestock. Taking this fact into consideration, many countries, including EU member states, practice complete elimination of infected and potentially infected animals and ban the vaccination against CSF.

Recently the first marked subunit vaccine against CSF, based on the application of the main protective antigen E2 of CSFV glycoprotein [1], has appeared on the market. However, the literature data testify that it is less efficient than, for instance, attenuated vaccine of strain C. Since the intensity of humoral immune response is a key factor, determining the possibility of infecting animals with CSFV and the development of long-term symptom-free virus carriage [2], the search 
for efficient marked vaccine against this disease is an urgent trend of veterinary virology.

In the prevailing numbers of works, dedicated to the creation of marked DNA-vaccine against CSF, a complete sequence of glycoprotein E2 CSFV was used [3-5]. At the same time it is suggested to differentiate between vaccine-induced and post-infectious immunity of animals by test-systems determination of antibodies to $E^{\text {rns }}$. It should be noted that the creation of DNA-vaccine in the works $[6,7]$ involved the application of E2 gene fragments, not containing the sequence, encoding the signaling peptide and transmembrane domain, while all antigenic subdomains were preserved similarly to a wild type protein.

In our previous work we reported about the creation of candidate marked DNA-vaccine against CSF on the basis of the gene fragment, coding for antigenic subdomains A and D of glycoprotein E2 CSFV [8].

The approach, proposed by us, is advantageous by the application of different antigenic subdomains of E2 for the elaboration of both marked DNA-vaccine and recombinant protein-based diagnosticum which will allow increasing the accuracy of differentiation between vaccineinduced and post-infectious immunity in animals due to the simultaneous detection of antibodies against two protective antigens of $\mathrm{E} 2$ (subdomains $\mathrm{B}$ and $\mathrm{C}$ ) and $\mathrm{E}^{\mathrm{rms}}$.

The recent literature data have shown that the booster immunization with recombinant protein [9] or recombinant virus, for instance, adenovirus [10, 11], after the priming with DNA-vaccine may result in considerable increase in the immune response to DNA-vaccination.

Therefore, this work was aimed at the investigation of an impact of the booster immunization with recombinant fragment of E2 CSFV on the humoral immune response, induced by candidate marked DNA-vaccine against CSF.

Materials and Methods. The strains of Escherichia coli Sure ${ }^{\circledR} 2$ (Stratagene, USA) and BL 21 (DE3) (Novagen, Germany) were used in the work. The preparations of plasmid DNA were isolated and purified by alkaline lysis with subsequent phenol/chloroform extraction in accordance with the methods, described in [12-14].

Immunization. The experiments were conducted on female mice of BALB/c line (breeding of IMBG, NAS of Ukraine), 2-2.5 months old. All the manipulations with animals were conducted using sedative and anesthetic preparations in compliance with the requirements of veterinary legislation. To study the expression of E2 CSFV fragment in situ the animals $(n=6)$ were injected intramuscularly with $100 \mu \mathrm{g}$ of pTR-BKneo, dissolved in $100 \mu 1$ of the saline, into the biceps. The control animals were injected with $100 \mu \mathrm{g}$ of the initial vector $p T R$-UFneo. The expression of the fragment studied was monitored on the third day after the injection. The scheme of combined immunization is described in Results and Discussion. The number of animals in each group was seven. The blood for isolation of serum was obtained by retro-orbital puncture on the 21, 42 and $65^{\text {th }}$ days after the beginning of the immunization; blood serum was obtained as described in [8].

The immunohistochemical determination of the expression of E2 CSFV fragment in situ. On the $3^{\text {rd }}$ day after the injection of the plasmid DNA preparation the mice were euthanized. The biceps was isolated, placed on the objective table of the cryostat device at the temperature of $-25{ }^{\circ} \mathrm{C}$ and serial $20 \mu \mathrm{m}$-thick cuts were made with subsequent fixation with $0.25 \%$ aqueous solution of glutaric dealdehyde for $5 \mathrm{~min}$. The immunohistochemical determination of the E2 fragment expression was conducted by the following method: primary antibodies were applied to the sections (hyperimmune swine serum obtained according to [8] in the working dilution of 1:1000 in phosphate-saline buffer, $\mathrm{pH} 7.4$, containing $0.05 \%$ twin-20 (PSBT) and $1 \%$ skim milk. Then the sections were incubated at the temperature of $37^{\circ} \mathrm{C}$ for $2 \mathrm{~h}$ and washed with PSBT three times with subsequent introduction of antibodies against swine immunoglobulins (Sigma, USA), conjugated with horseradish peroxidase in the working dilution of 1:500. [Next,] They were incubated for $2 \mathrm{~h}$ and washed with PSBT five times. 3-aminoethylcarbasol (Sigma) was used as chromogen. The sections were additionally stained with $1 \%$ aqueous solution of azur-II.

The total DNA from the biceps tissue was extracted by the mixture of phenol-chloroform according to the method described in [15].

The detection of E2 CSFV fragment by PCR. A pair of primers was selected to detect the transgene using PCR: E2asn - 5'-GGCACCAAAATCAACG GGAC-3' and E2sn - 5'-GGGAGTCCGTC 
AGCCTCAT-3'. The reaction mixture contained 100 ng of total DNA. The amplification of the fragment of glycoprotein E2 CSFV was conducted on DNAamplifier Tercik (DNA-technologies, RF) using the following scheme: DNA denaturation $-95^{\circ} \mathrm{C}, 30 \mathrm{~s}$; annealing primers $-60^{\circ} \mathrm{C}, 30 \mathrm{~s}$; elongation $-72^{\circ} \mathrm{C}, 1 \mathrm{~min}$. After the process the amplification products were separated using the gel-electrophoresis method in $0.8 \%$ agarose gel.

The expression of the fragment $E 2 C S F V$ in $E$. coli BL21 (DE3) and its purification. The bacterial culture was cultivated in nutrient media: LB [12], Bacto ${ }^{\mathrm{TM}}$ Brain heart infusion Porcine (BD Biosciences, USA) (hereinafter medium II) and Bacto NZCYM Broth (Difco, USA) (hereinafter medium NZCYM), containing kanamycin and glucose in the final concentration of $50 \mu \mathrm{g} / \mathrm{ml}$ and $0.5 \%$ respectively. The inoculate of E. coli cells BL(DE3)/pET24ap -csfcrev, previously cultivated at $37{ }^{\circ} \mathrm{C}$ for $16-18 \mathrm{~h}$, was introduced into the nutrient medium. The volume ratio of inoculate and nutrient medium was 1:100. The culture was cultivated upon intense aeration $(160 \mathrm{rpm})$ at $37^{\circ} \mathrm{C}$ until reaching the optic density of $\mathrm{A} 600=2$; to induce the target product synthesis we added the solution of isopropyl- $\beta$-D-thiogalactoside (IPTG, MBI Fermentas, Lithuania) to the final concentration of 1 $\mathrm{mM}$ and continued the cultivation of producent strain under the same conditions during 4-16 h. The inclusion bodies, containing E2 fragment, were isolated in accordance with [16] and solubilized in the buffer solution, containing $8 \mathrm{M}$ urea and 0.1 M DTT. The solubilized protein was transferred into the buffer solution without urea and DTT using gel-filtration on Sephadex G-25 (GE Healthcare, USA). The chromatographic purification of preparations was performed on Q Sepharose XL (GE Healthcare). The fractions obtained were analyzed by gel-electrophoresis using Laemmli's method in $13 \%$ SDS-PAAG [12]. The content of the target protein in the lysate of $E$. coli cells was estimated using the densitometry of electrophoregrams with subsequent analysis in Total Lab software (USA).

The antibodies, specific to E2 CSFV in murine blood serum, were detected by ELISA according to [8]. The results are presented as the average value of optic density index at the used dilution \pm average deviation $(n=7)$. In order to assess the relevance of discrepancies we used the non-parametric Mann-Whitney criterion (U). The index of seroconversion was calculated as the percentage ratio of the number of animal sera with titers of anti-E2 antibodies $>1 / 50$, obtained after the vaccination to the total number of the sera studied. The results are presented as the average value of the index (obtained in three groups, seven animals in each).

Results and Discussion. In our previous work we showed in vitro that the introduction of developed recombinant plasmid pTR-BKneo in the cells of CHO-K1 line leads to the expression of E2 CSFV fragment [8]. One of the key stages in the elaboration of DNA-vaccines as well as other gene-based therapeutic preparations is the confirmation of the transfer of genetic material, namely, a target gene or genes into the target cells of the recipient organism and confirmation of the functional activity of the developed recombinant molecules in situ. The presence of transgene in the zone of the administration and expression of the target protein was studied on the 3 rd day after the intramuscular injection of $p T R-B K n e o^{-}$. A pair of primers was designed to test the transgene using PCR: E2asn - 5'GGCACCAAAATCAACGGGAC-3' and E2sn 5'-GG GAGTCCGTCAGCCTCAT-3' (Fig.1). The length of the expected PCR-fragment is 701 b.p. The PCR-analysis of the samples of total DNA, isolated from the biceps tissue, demonstrated the presence of the transgene of the fragment of E2 CSFV in the biceps cells of experimental animals, which is evidenced by the band of expected size on the electrophoregram of PCR-reaction products (Fig.2). At the same time this fragment is absent in the control samples. Therefore, the obtained data revealed that the developed construct pTR-BKneo, administered by the chosen route, transforms in situ the biceps cells.

The target antigen expression was studied by immunohistochemical method on the $3^{\text {rd }}$ day after the introduction of the candidate marker DNA-vaccine. The results obtained testify to the fact that the target antigen is expressed by the biceps myocytes on the $3^{\text {rd }}$ day after the intramuscular introduction of the investigated DNA-vaccine (Fig.3). However, the percentage of transfected cells turned out to be small $2.42 \pm 0.17 \%$, which is in good agreement with the 

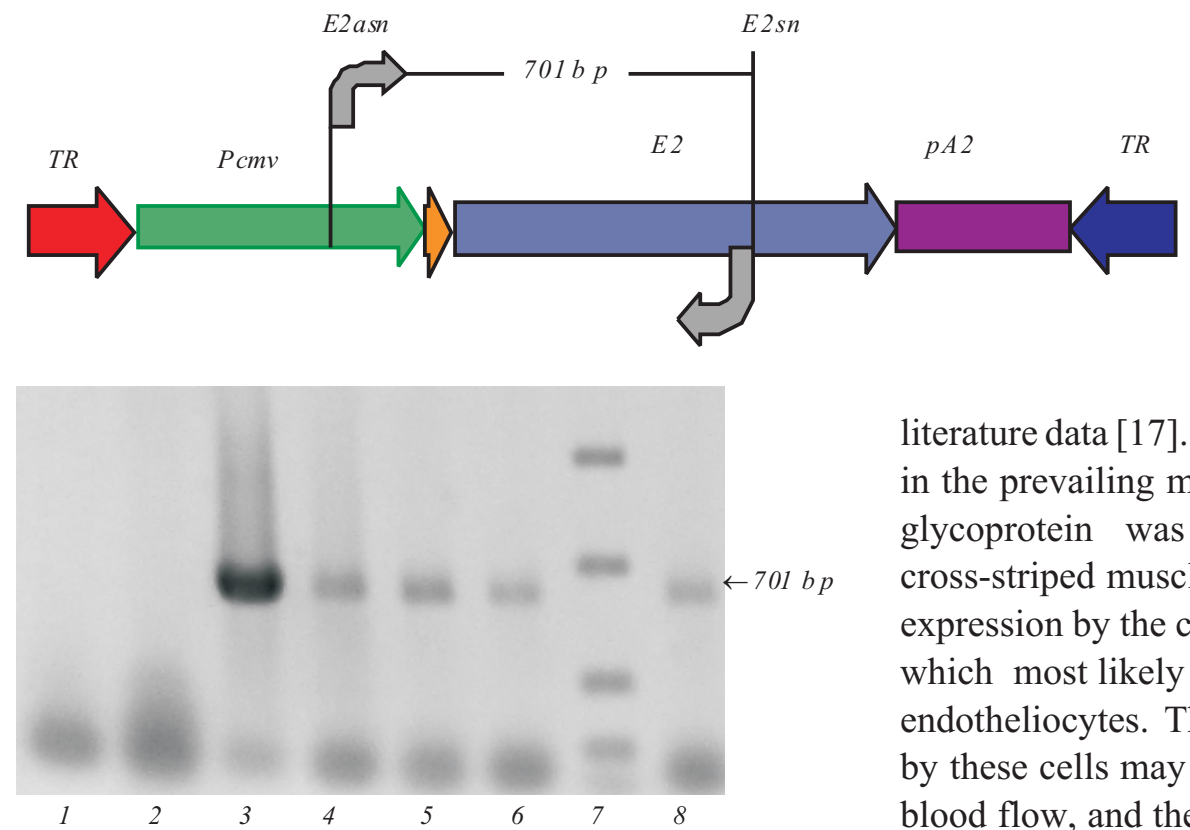

Fig. 2 The electophoregram of PCR products, obtained using primers E2-sn/E2-asn: 1 - sample without DNA (control); 2 - total DNA extracted from biceps cells on the $3^{\text {rd }}$ day after the introduction of plasmid DNA; 3 - pTR-BKneo; 4-6, 8 - total DNA extracted from biceps cells on the $3^{\text {rd }}$ day after the introduction of pTR-BKneo $; 7-$ marker (FastRuler ${ }^{\mathrm{TM}}$ DNA Ladder, Low Range, Fermentas). The size of PCR products is indicated with an arrow.
Fig. 1 The scheme of the location of primers in the fragment of glycoprotein gene E2 CSFV relative to its structural map in the composition of plasmid $p T R-B K n e o ; T R-$ inverted terminal repeats AAV-2; Pcmv human cytomegalovirus immediate-early enhancer/promoter; E2 - SacI-EcoRI-fragment of E2 CSFV gene; pA2 - signal of polyadenylation literature data [17]. It should be also noted that although in the prevailing majority of cases the fragment of E2 glycoprotein was expressed by the cells of cross-striped muscles, there were single variants of its expression by the cells of the vessel wall of the venule, which most likely are the cells of smooth muscles or endotheliocytes. The expression of the target antigen by these cells may provide its direct occurrence in the blood flow, and therefore possible enhancement of the immune response due to the contact with a large number of antigen-presenting cells in the draining lymph nodes, spleen etc.

The action of booster immunization was studied using recombinant fragment E2 CSFV, obtained in $E$. coli cells. Although the recombinant protein is not
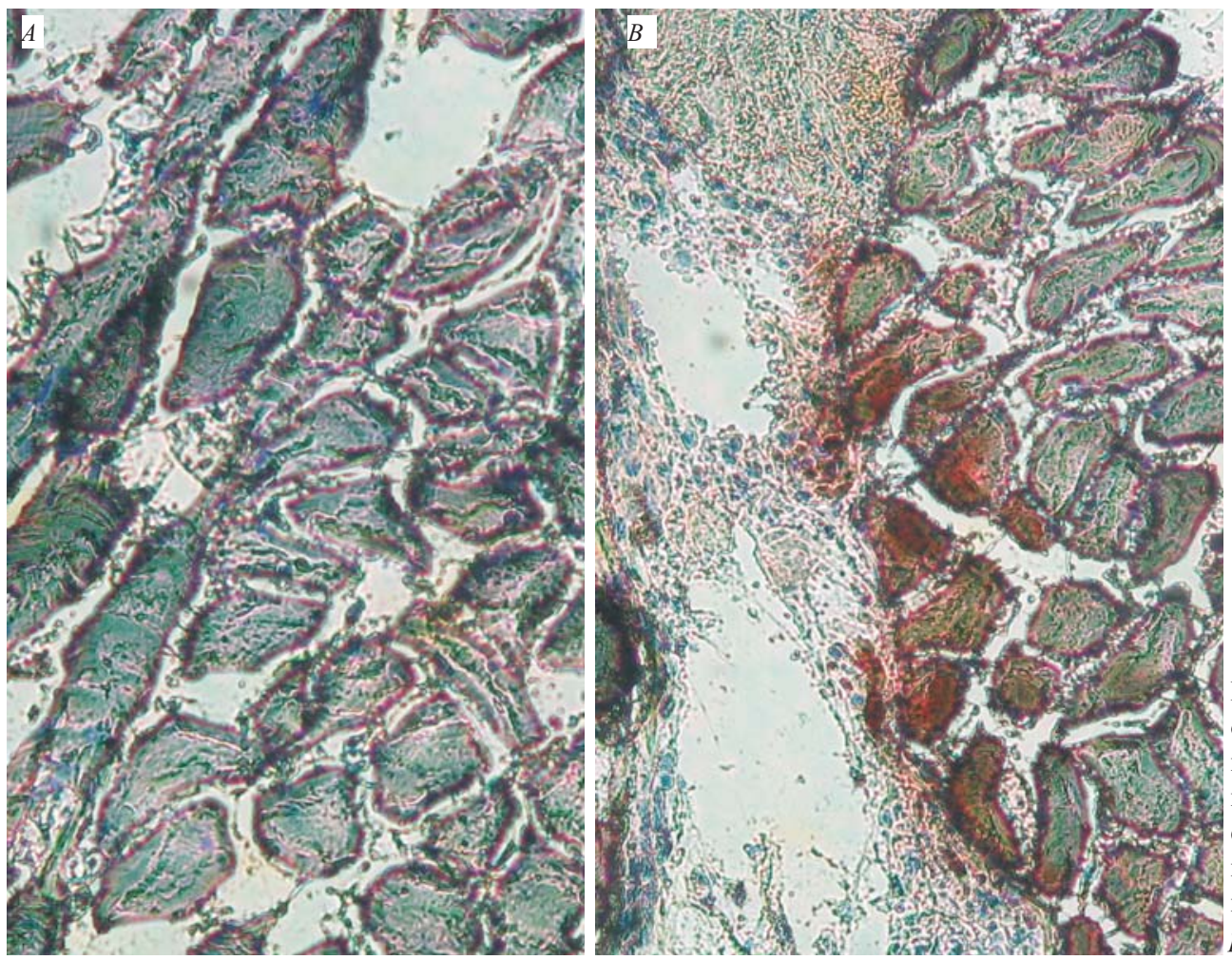

Рис. 3. Иммуногистохимическое определение экспрессии фрагмента гликопротеина Е2 ВКЧС в клетках бицепса мы- ши на 3-и сут после введения: $a-$ контрольная группа; $\sigma$ - экспериментальная группа, ко- торой вводили pTR-BKneo . $\times 400$ 


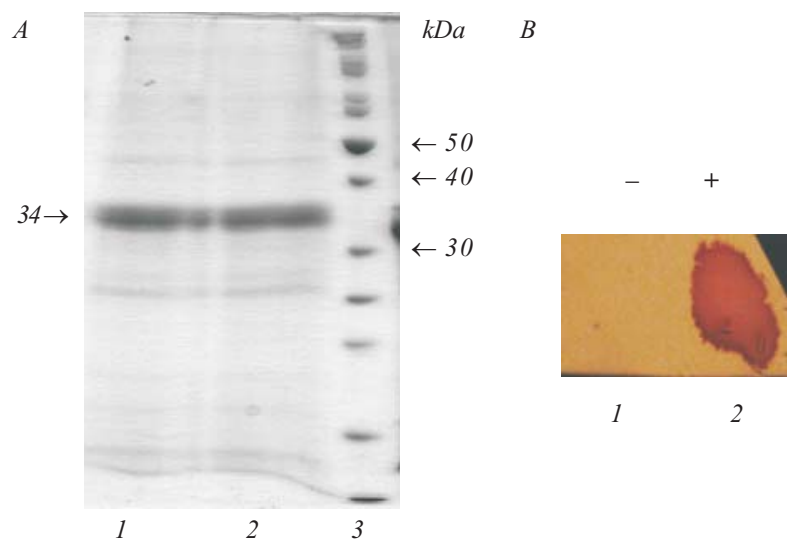

Fig. 4 The electrophoregram of aliquots, obtained after the renaturation and purification of E2 CSFV fragment (1,2- fractions, isolated after consecutive chromatographies on Sephadex G-25 and Q Sepharose $\mathrm{XL} ; 3$ - marker of molecular weight of proteins, PageRuler ${ }^{\mathrm{TM}}$ Unstained Protein Ladder, Fermentas) $(A)$ and the results of dot-blotting analysis of E2 CSFV fragment (1 - proteins of the soluble fraction of cell lysate BL21 (DE3); 2 - E2 CSFV fragment) (B)

glycosilated in E. coli cells, it was previously demonstrated that the immunization of swine with this fragment elicited a protective immune response, sufficient to protect the animals against the challenge with CSFV, strain Washington [16].

To enhance the yield of the target antigen we optimized the conditions of cultivating the producent strain BL21 (DE3)/pET24ap-csfc@rev, developed previously [16]. It was shown that the cultivation on complex nutrient media LB, II and NZCYM results in the synthesis of the target product with the molecular weight of $34 \mathrm{kDa}$. The accumulation of the target protein is $0.152 \mathrm{~g}$ out of 11 of the culture of bacterial cells using the LB medium, and $0.4 \mathrm{~g}-$ using II medium. The target protein synthesis by the producent cells cultivated in the NZCYM medium was not detected by gel-electrophoresis in $13 \%$ polyacrylamide gel under denaturing conditions with Coumassie staining, but it was detected by Western-blot analysis. The level of fragment of E2 CSFV production is 19.54 and $35.62 \%$ at cultivation during $12-18 \mathrm{~h}$ after the IPTG introduction into LB and II media, respectively. Taking this fact into consideration, only II medium was used in further experiments. It was shown that decreasing the IPTG concentration in the range of 1 to 0.1 $\mathrm{mM}$ results in almost 2-fold lower output of the target product. The analysis of the dynamics of product accumulation revealed the increased amount of E2 in the

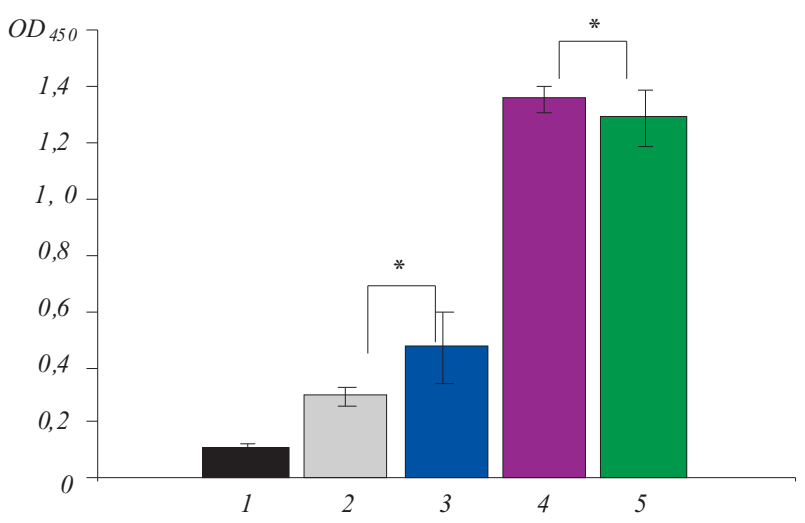

Fig. 5 The results of ELISA of blood serum of mice after the third immunization: 1 - control animals, which were administered with pTR-UFneo ; 2, 3-animals, which were vaccinated three times with candidate marker DNA-vaccine $(2-$ seven days after the third immunization; 3 - a month later); 4, 5- animals, vaccinated twice with candidate marker DNA-vaccine, and vaccinated with E2 fragment for the third time $(4-$ seven days after the third immunization; 5 - a month later). The data are presented for the sera in the working solution with dilution of $1: 400 ; \mathrm{p}$ ? $0.01 ;{ }^{*} \mathrm{p}>0.05$.

cells after $12-18 \mathrm{~h}$ cultivation compared to that $4 \mathrm{~h}$ after the inductor introduction.

Therefore, the maximal level of the E2 CSFV synthesis (up to $0.4 \mathrm{~g} / 1$ of the cultivation medium) was observed while cultivating the culture for] $12-18 \mathrm{~h}$ after the introduction of IPTG (to the final concentration of $1 \mathrm{mM}$ ) on II medium. The study on the distribution of the synthesized fragment of E2 CSFV in E. coli cells demonstrated that it was accumulated only as inclusion bodies, which were subsequently isolated after the cells lysis, solubilized in the buffer with a chaotropic agent, and renatured. The binding of the preparation of recombinant E2 in vitro with the antibodies of hyperimmune porcine serum, obtained as previously described [8] was used as a test, providing for the assessment of the accuracy of antigen determinant formation during renaturation of E2 fragment in vitro with subsequent checking by dot-blotting (Fig.4).

The experiments studying the action of booster immunization with E2 CSFV on the immune response, induced by marker DNA-vaccine against CSF, were conducted in accordance with the following scheme: the animals were injected intramuscularly with $100 \mu \mathrm{g}$ of candidate marker DNA-vaccine with the two-week interval. The booster immunization was conducted three weeks after the second immunization, using the 
same dose of DNA-vaccine for one group, and $30 \mu \mathrm{g}$ of the recombinant fragment of E2 CSFV - for the second. The analysis of the data obtained revealed that the seroconversion index after the second immunization was $\approx 54 \%$, and $100 \%$ after the third one. This index did not change in a month since the third immunization. The results of serum analysis testify that the booster immunization with E2 CSFV after two immunizations with marker DNA-vaccine leads to a more significant increase in the titer of antibodies to the target antigen compared to three immunizations with DNA-vaccine (Fig.5). It should also be noted that there was no reliable sharp decline in the titer of antibodies to E2 in a month since the booster immunization.

Conclusions. The primers, which allow testing the presence of the transgen of E2 CSFV in the cells of murine skeletal muscles, were designed. It was confirmed that pTR-BKneo in situ transforms the biceps cells and the fragment of E2 CSFV is expressed from the introduced plasmid construction. It was demonstrated that on the $3^{\text {rd }}$ day after the introduction of the candidate marker DNA-vaccine against CSF the target antigen is mainly expressed in the myocytes of skeletal muscle tissue.

The investigations, aimed at the optimization of conditions of the E2 CSFV in E. coli cells, strain BL21 (DE3), demonstrated that the accumulation of the target protein is at least $0.4 \mathrm{~g}$ from 11 of the culture of bacterial cells when using the selected conditions of cultivation on the medium BactoTMBrain heart infusion Porcine.

It was revealed that the seroconversion index after double immunization with candidate marker DNA-vaccine was $\approx 54 \%$, while the booster immunization with the same DNA-vaccine or recombinant fragment of E2 CSFV increased this index to $100 \%$.

Therefore, it may be assumed that the application of the booster immunization with recombinant E2 promotes the elicited humoral immune response to the candidate marker DNA-vaccine against CSF. It is noteworthy that the booster immunization with the recombinant protein results in a more considerable increase in the titer of antibodies to the target antigen compared to the studied DNA-vaccine.
Я. А. Похоленко, Т. П. Гулько, Е. Г. Дерябина, В. А. Кордюм

Влияние бустерной иммунизации фрагмента Е2 ВКЧС на иммунный ответ, индуцированный маркированной ДНК-вакциной против КЧС

Институт молекулярной биологии и генетики НАН Украины Ул. Академика Заболотного, 150, Киев, Украина, 03680

${ }^{1}$ Институт ветеринарной медицины НААН Украины

Ул. Донецкая, 30, Киев, Украина, 03151

Резюме

Цель. Исследовать влияние бустерной иммунизаиии рекомбинантным фрагментом Е2 ВКЧС на гуморальный иммунный ответ, индуцированный кандидатной маркированной ДНК-вакичной против КЧС. Методы. Наличие фрагмента гена Е2 ВКЧС детектировали методом ПЦР, а экспрессию белка продукта этого гена - иммуногистохимическим методом. Титр антител, специфичных к иелевому антигену, в сыворотке крови после иммунизации определяли с использованием ИФА. Результаmы. Продемонстрировано, что кандидатная маркированная ДНК-вакиина трансфецирует іп situ миочиты бицепса. На основе данных иммуногистохимического анализа установлено, что с введенной плазмидной конст- рукиии осуществляется экспрессия фрагмента Е2 ВКЧС. Бустерная иммунизачия рекомбинантным фрагментом Е2 ВКЧС после двух иммунизачий маркированной ДНК-вакциной приводит к увеличению титра антител к целевому антигену по сравнению с трехкратной иммунизацией ДНК-вакциной. Выводы. Результаты проведенных исследований свидетельствуют о том, что использование бустерной иммунизации рекомбинантным фрагментом Е2 способствует усилению гуморального иммунного ответа на кандидатную маркированную ДНК-вакиину против КЧС.

Ключевые слова: маркированная ДНК-вакцина, бустерная иммунизаиия, гуморальный иммунный ответ, вирус классической чумы свиней.

\section{Я. О. Похоленко, Т. П. Гулько, О. Г. Дерябина, В. А. Кордюм}

Вплив бустерної імунізації фрагментом Е2 ВКЧС на імунну відповідь, індуковану маркованою ДНК-вакциною проти КЧС

\section{Резюме}

Мета. Дослідити вплив бустерної імунізаиії рекомбінантним фрагметом Е2 ВКЧС на гуморальну імунну відповідь, індуковану кандидатною маркованою ДНК-вакииною проти КЧС. Методи. Наявність фрагмента гена Е2 ВКЧС детектували методом ПЛР, а експресію білка - продукту цьього гена - імуногістохімічним методом. Титр антитіл, специфічних до цілььового антигену, у сироватиі крові після імунізачї визначали, використовуючи ІФА. Результати. Продемонстровано, що кандидатна маркована ДНКвакиина іп situ трансфікує міочити біџепса. На основі даних імуногістохімічного аналізу встановлено, що з введеної плазмідної конструкиії здійснюється експресія фрагмента Е2 ВКЧС. Бустерна імунізація рекомбінантним Е2 ВКЧС після двох імунізацій маркованою ДНК-вакииною спричиняе зростання титру антитіл до иільового антигену у порівнянні з триразовою імунізацією ДНК-вакииною. Висновки. Результати проведених досліджень свідчать про те, що використання бустерної імунізачії рекомбі- 
нантним фрагментом Е2 сприяє посиленню гуморальної імунної відповіді на кандидатну марковану ДНК-вакичну проти КЧС.

Ключові слова: маркована ДНК-вакцина, бустерна імунізація, гуморальна імунна відповідь, вірус класичної чуми свиней.

\section{REFERENCES}

1. Beer M., Reinmann I., Hoffman B., Depner K. Novel marker vaccines against classical swine fever // Vaccine.-2007.-25, N 30.-P. 5665-5670.

2. Vasilyev D. A., Lugovtcev V. Iu. The course of lectures in virology // Viruses causing diseases of swine.-Ulyanovsk: USAA, 2004.-Part 3.-85 p

3. Tarradas J., Alvarez B., Fraile L., Rosell R., Munoz M., Galindo-Cardiel I., Domingo M., Dominguez J., Ezquerra A., Sobrino $F$., Ganges L. Immunomodulatory effect of swine CCL20 chemokine in DNA vaccination against CSFV // Vet. Immunol. Immunopathol.-2011.-142, N 3-4.-P. 243-251.

4. Wienhold D., Armengol E., Maroquardt A., Maroquardt C., Voigt H., Buttner M., Saalmuller A., Pfaff E. Immunomodulatory effect of plasmids co-expressing cytokines in classical swine fever virus subunit gp55/E2-DNA vaccination // Vet. Res.-2005.-36, N 4.-P. 571-587.

5. Ganges L., Barrera M., Nunez J. I., Blanco I., Frias M. T., Rodriges $F$., Sobrino $F$. A DNA vaccine expressing the E2 protein of classical swine fever virus elicits $T$ cell responses that can prime for rapid antibody production and confer total protection upon viral challenge // Vaccine.-2005.-23, N 28.-P. 3741-3752.

6. Makowska-Daniel I., Collins R. A., Pejsak Z. Evaluation of genetic vaccine against classical swine fever // Vaccine.-2001.-19, N 17-19.-P. 2480-2484.

7. Yu X., Tu C., Li H., Hu R., Chen C., Li Z., Zhang M., Yin Z. DNAmediated protection against classical swine fever virus // Vaccine.-2001.-19, N 11-12.-P. 1520-1525.

8. Pokholenko I. A., Ruban T. O., Sukhorada O. M., Deriabin O. M., Tytok T. G., Kordium V. A. The development of DNA-vaccine against classical swine fever // Biopolym. Cell.-2007.-23, N 2.P. 93-99.
9. Schneeweiss A., Chabiersli S., Salomo M., Delaroque N., Al-Robaiy S., Grunwald T., Burki K., Liebert U. G., Ulbert S. A DNA vaccine encoding the E protein of West Nile virus is protective and can be boosted by recombinant domain DIII // Vaccine.2011.-29, N 37.-P. 6352-6357.

10. Zhao H. P., Sun J. F., Li N., Sun Y., Wang Y., Qui H. J. Primeboost immunization using alphavirus replicon and adenovirus vectored vaccines induces enhanced immune responses against classical swine fever virus in mice // Vet. Immunol. Immunopathol.-2009.-131, N 3-4.-P. 158-166.

11. Hammond J. M., Jansen E. S., Morrissy C. J., Goff W. V., Meehan G. C., Williamson M. M., Lenghaus C., Sproat K. W., Andrew M. E., Coupar B. E., Johnson M. A. A prime-boost vaccination strategy using naked DNA followed by recombinant porcine adenovirus protects pigs from classical swine fever // Vet. Microbiol.-2001.-80, N 2.-P. 101-119.

12. Sambrook J., Fritsch E. E., Maniatis T. Molecular cloning.Cold Spring Harbor Lab. press, 1989.-625 p.

13. Yamamoto T., Horikoshi M. Rapid preparation of plasmid templates suitable for a DNA sequences without RNAse treatment // Nucleic Acids Res.-1995.-23, N 16.-P. 3351-3352.

14. Current protocols in molecular biology / Eds F. M. Ausubel et al.-New York: John Wiley \& Sons, Inc., 1997.-Vol. 1.P. 1.7.9-1.7.10.

15. DNA vaccines: methods and protocols / Eds D. B. Lawrie, R. G. Whalen.-New York: Humana press, 2000.-529 p.

16. Deryabin O., Kulinich R., Deryabina O., Reznik V. Protective properties of the Classical Swine fever virus E2 recombinant protein expressed in E. coli // Herald of Bila Tserkva National Agrarian University.-2005.-31.-P. 151-158.

17. Dupuis M., Denis-Mize K., Woo C., Goldbeck C., Selby M. J., Chen M., Otten G. R., Ulmer J. B., Donnelly J. J., Ott G., McDonald D. M. Distribution of DNA vaccines determines their immunogenicity after intramuscular injection in mice // J. Immunol.-2000.-165, N 5.-P. 2850-2858. 